Original Research Paper

\title{
Interactive Module Development of Teacher's Measurements
}

\author{
Mohd Razimi Husin $^{1 *}$, Ismail Yusuf Panessai ${ }^{2}$, Hishamuddin Ahmad ${ }^{1}$ \\ ${ }^{1}$ Department of Educational Psychology, Faculty of Human Development, Universiti \\ Pendidikan Sultan Idris, Malaysia. \\ ${ }^{2}$ Department of Artificial Intelligence, Faculty of Computer Science and Information \\ Technology, Universiti Malaya, Malaysia.
}

Article History
Received:
27.08.2018
Revised:
12.10.2018
Accepted:
21.11 .2018
*Corresponding Author:
Mohd Razimi Husin
Email:
razimi@fpm.upsi.edu.my

Article History

\section{Received:}

Revised:

12.10.2018

\section{Accepted:}

Mohd Razimi Husin

razimi@fpm.upsi.edu.my
Abstract: This research develops an interactive module system that can be used to explore and build a self-assessment checklist on significant learning content in the daily life and work of students in the future. The purpose of this interactive module system is to contribute to the teacher in choosing the appropriate learning content for teaching. This study will focus on the contents of Form 1 history subjects involving teachers and students. The built-in interactive module system also benefits pupils when the learning takes place content and skills that can be used all the time. The data were obtained through field observations in the classroom and teacher work. In general, the use of interactive module systems developed is very good and effective. The findings show that the majority of users have stated that the developed system interface is of interest to the user, in which the navigation system developed is user-friendly. The user states that the usability of the developed system is very helpful to teachers and students in understanding the content of the given lessons.

Keyword: Self Measurement, Learning Content, Interactive Module System, Courseware. 


\section{Introduction}

The National Education Policy that wants pupils to progress in terms of intellectual, spiritual, physical, emotional and social needs to be realized. How to generate balanced human beings also begins when children enter the preschool nature to ensure that every Malaysian can perform quality life when they become adults [1]. In general, the policies in the implementation of all types of education are either national policies or international declarations so that pupils can be educated at the highest level to enable them to find employment and live independently [2]. The Malaysian Education Development Plan 2013-2025 plans to increase the quality of education delivery. The focus is on the mastery of the people of the younger generation, especially in the STEM (Science, Technology, Engineering, and Mathematics) education which also emphasizes the aspects of the High-Level Thinking Skills [3]. According to Suppiah, et. al. [4], experience in creating skills related tasks require more time at first.

The contents of the Science subject in the Curriculum Specification of the Ministry of Education Malaysia (MOE) are largely related to everyday life. Among the contents of the lesson are body coordination, energy, chemical change, light, colour, vision and more [5]. Only psychological and management tests and the like are produced by Malaysian training, psychology and counselling institutes [6]. Since the new curriculum describes only the content, it is the responsibility of the implementer to realize the content in the most beneficial form of the student [7].

Students will learn something meaningful if able to present things learned without the help and presence of teachers. If students rely on teachers, the ability to develop skills and limited thinking and slow down success in the chosen field [8]. The disadvantages are not only to complicate teachers in the delivery of knowledge and skills to students, but also involve aspects of learning that need to be applied with various techniques and skills involving the environment, emotion, sociology, physiology and psychology [9], [10], [11], [12]. Measurements and learning techniques to be built should be closely related to students' condition [11], [12], [13], [14].

According to Kementerian Pendidikan Malaysia [15] that parents, teachers and others are encouraged to share information, monitor developments and build a profile that will explain the difficulty of children and determine a positive way to help them. Teachers need to convince students about their strengths and abilities in many ways that can help them overcome difficulties such as receiving responses through drawing or flow charts rather than through conversations or writing. One of the most widely used drawings or drawings in education and teaching is the interactive module system known as the courseware.

This study was conducted to identify the suitability of the interactive module system to be developed by looking at the comparison between existing systems. With the review and evaluation done, it will be guided to improve the shortcomings and make improvements and updates on the interactive module system to be developed. There are two systems that are used as a review of the Lifter LMS and WP Courseware.

\section{Interactive Module Design}

The waterfall model approach to developing interactive modules (or also known as software) is used because it has some development methods and development flows that are appropriate for this software. In addition, waterfall also has deeper and more detailed phases of how this software works and has a great impact on teachers and students in understanding a subject. Additionally, this model also has a testing phase where this software will be tested on its effectiveness against users after they are completed through the design phase. Through this testing phase, we can improve or improve this software if it still needs more effective software so that the objectives and goals of this software can be achieved successfully.

\subsection{Information and Analysis Collection Phase}

It is the first phase contained in the waterfall methodology model where it involves the process of collecting and analyzing data and information in detail and accuracy. In the phases of all information such as scope, user background and gadget specifications are in-depth to make it easier to extend the development process to the next phase. This phase begins with an analysis of the information needed to develop the courseware.

In this study, the method of interviewing and searching for scientific materials was chosen to obtain information or preliminary data on the need to develop this software. Interview with Dr. Mohd 
Razimi bin Husin describes the description of the interactive modules to be developed including the problem statement and the contents of each display in the toolbox. Furthermore, in-depth studies are made on the need for a statement of the problem to identify the needs and then these identified needs are arranged according to priority requirements. The selection to generate and evaluate alternative management processes is also considered in this phase. Once information is obtained and recorded, the information is collected for analysis. Information that has been analyzed will be used in logical and physical modeling and ready for the implementation of the interactive module design phase. In this study, interactive modules developed will be used as a platform to help teachers and students better understand the topics taught through the actual picture display or demonstrate clear demonstrations. To develop this interactive module, hardware and software requirements need to be studied.

Teacher planning plays an important role in ensuring that pupils can explore useful information and skills at all times. Require suitable sources of material whether used materials, computer software and others. According to Suppiah et al. [4] experience in creating skills related tasks require more time at first. Skills orality involves oral delivery of teachers to students according to the suitability of the method of delivering a particular topic [16].

In binary method, a binary form of $e$ is processed in a sequence of doublings and an optional additions depends upon the given digit value that is 1 or 0 respectively.

\subsection{Software Justification}

The software can be defined as a set of instructions (computer programs) that are formed to perform certain tasks or functions. The software that will be used in the process of developing interactive models in this study is Adobe Flash. Adobe Flash Player is a runtime that performs and displays content from a .SWF file provided, although it does not have features built to modify SWF files during runtime. .SWF can execute software written in Action Script programming language that allows the manipulation of text, data, vector graphics, raster graphics, sound, and video manipulation. Players may also access certain connected hardware devices, including webcam and microphone after the same authorization has been granted by the user.

\subsection{Design Phase}

The second phase is the design phase. This phase plays the most important role because it must meet and achieve project goals and objectives solving user problems. In this phase should be given more attention. Every important elements such as the use of text, audio, video, and graphics should meet the user's scope and background. In addition to building a simple and interesting interface and easy to understand, it should also be able to communicate information and relevant information to users. Software design refers to the selection and determination of methods or technologies for development informative software.

The purpose of this phase is to represent the data and relationships between the data and to ensure that the design meets the needs of the customer based on the data analysis that has been obtained. In this phase will also determine how interactive modules will interact with the user in terms of input and output (input/output). Every information obtained from the analysis phase will be useful for planning the strategy to be used to develop the desired software. There are several principles of interactive module construction that should be considered in producing good interactive modules. Good design strategies require a good framework and use appropriate approaches.

\subsection{Development Phase}

The next phase is the phase of development. Once the design phase is completed, this phase will involve its use in the real-time software. All designs that have been deployed will be made as a courier using Adobe Flash software and the gadget specifications will also be considered whether or not it is appropriate. In this phase, everything that has been designed will be translated into the form of code. Computer programs are written using conventional programming languages. Programmatic tools such as compilers, interpreters, debuggers are used to generate codes. Then the information will be reviewed and the data ready to be generated and used. The actual data is included in the courseware and the report preparation process is tested. This phase will determine which developed software is able to operate without any problems. In addition to seeing the progress of the software 
that will be used in the creation of this software, we must also emphasize the cost and time to carry out this phase.

\subsection{Verification Phase}

The fourth phase is the verification phase. In this phase also involves the testing of the software or software. The test is to see the effectiveness of the software whether it can be run or not. In addition, this phase also aims to see and identify if this software has defects, bugs or blemishes due to wrong coding. This phase will be run until it reaches the actual function of the software. Once it has been successfully tested and given satisfactory results, once again the last test will be run this time to the user as an experiment. Here we can see and know how users will use it in reality. After receiving positive feedback from the user, this software will be verified for the next phase.

Completed kits will be tested to ensure the smoothness of the kits and also meet the needs of the users and the required specifications. It also examines the effectiveness and objective of this study to be achieved or not achieved. Comprehensive testing should be carried out before the use of the courseware. The printer is tested to ensure the interfaces of each module work, the software works on the desired platform with the expected amount of data and the cost of performing the activity requested by the user. This test involves all components of the courier and is completed when the courier passes the testing phase. This witch can already be used by the public after this phase.

\subsection{Maintenance Phase}

Once the software is tested and verified, evaluation and improvement are carried out for actual use of teachers and schoolchildren. Maintenance is implemented to address problems that may arise when the courseware is operated. This phase also involves user training ie to show users how to use the toolbox. Involving the installation of this software in real markets such as in schools and tuition centers. However, ongoing monitoring is still ongoing to see the effectiveness of this software. In this phase also suggestions and opinions from users can be developed into this software.

\subsection{Unit Testing}

Testing is done to identify and remove logical errors and implementation errors that can cause a system to fail normally.

Testing has been done in several aspects:

1. Error handling that works to handle errors from occurring during the execution of this system.

2. The interface works to check the incoming and outgoing parameters of this developed system.

3. A logical path that works to ensure every statement is tested at least once.

\subsection{Integration Testing}

This test is done after all models pass unit tests to see the effects when the modules are interconnected. This test ensures data can move well through the module interface and there is no problem with the data structure used. The modules will be integrated into several stages to form the modular system that is activated during the design phase. Integration testing can be made on the modular system defined during the design phase. Integration testing can be made on the system by performing testing on the system interface design.

\subsection{User Acceptance Testing}

Test user receiver is the last test before being handed over to the user. The goal is to assure that all needs have been made. A total of 30 students are randomly testing this system. Users are given the opportunity to use the system to verify the capabilities and objectives of this system has been achieved. Acceptance testing is done by providing questionnaires when users use this system.

\section{Summary and Conclusion}

The purpose of the user acceptance test is to make sure users can easily use the system. The level of user satisfaction and feedback will be the goal of this test. This test focuses on two areas - either the system interface and system functions.

Figure 1 shows the example of the title page in the developed software. Figure 2 shows the findings of the user acceptance test from 30 respondents. The questionnaire was distributed to 25 pupils and 5 teachers at random to test this system. 
Users are given the opportunity to use the system to verify the capabilities and objectives of this system has been achieved. The findings show that $65 \%$ of users stated that the built-in system interface is of interest to users, $40 \%$ of users have stated that the usability of the developed system is very helpful to teachers and students, $50 \%$ of users have stated that the navigation system developed is user-friendly and $70 \%$ expressing great satisfaction with the developed software system.

We conclude that all the subjects involved can be linked to the lesson content that is useful for the daily and future life of the students.

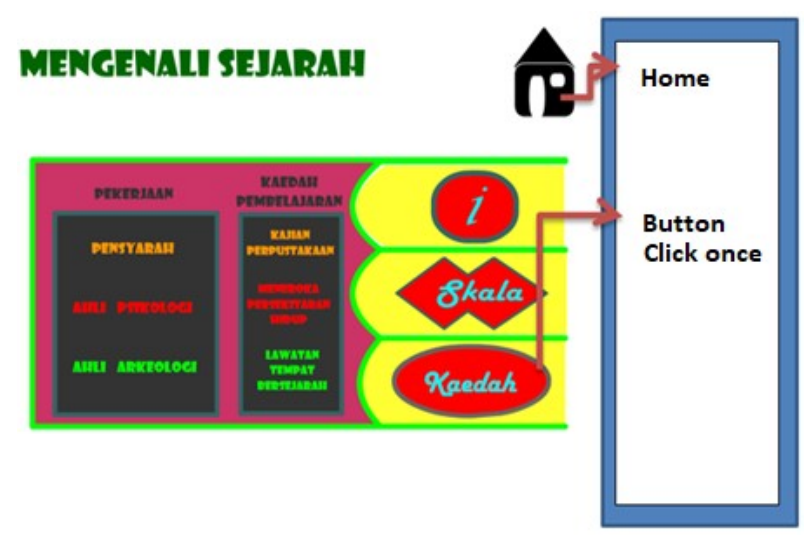

Figure 1. Page Example: Learning Method
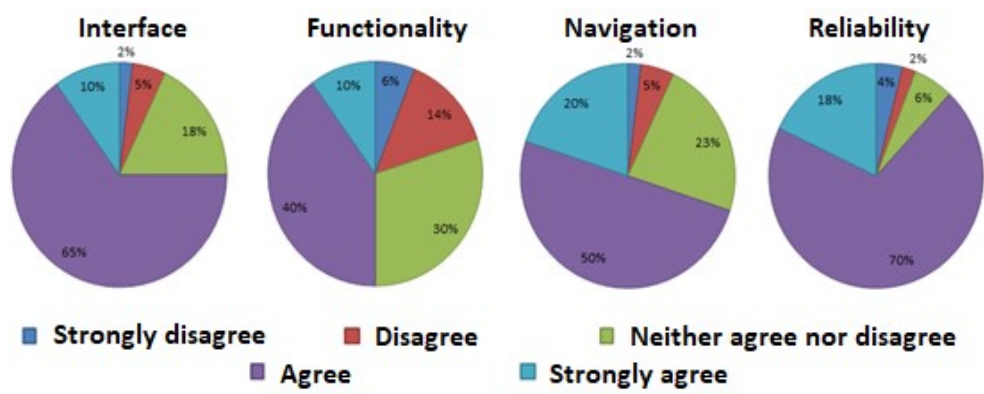

Figure 2. Findings: Interface, Usability, System Navigation, and User Satisfaction

However, content is useful or not depending on the way the implementation and planning of the teacher are to process the learning according to the suitability of the student. Teacher planning plays an important role in ensuring students can explore useful information and skills all the time. The experience of using such learning techniques will not only benefit students but will also facilitate the process of remembering the content to be delivered. Such teaching requires the appropriate source material for used materials, computer software, and others.

Through the results of user acceptance test results, the researcher found that the interactive toolkit of this one-tier history module works successfully and achieves the objectives set. $65 \%$ of users stated that the built-in system interface was of interest to the user, $40 \%$ of users claimed that the usability of the developed system was very supportive and students, $50 \%$ of users stated that the navigation system developed was user-friendly and $70 \%$ of users were very satisfied with the system developed software.

Therefore, it can be concluded that the development of a software system in this study helps teachers and students to better understand the topics they are teaching and their relevance to daily life and work. 


\section{References}

[1] M. R. Husin, "Exploring the Use of Digital Devices among Pupils with Learning Disabilities," The International Journal of Multimedia \& Its Application, vol. 9, December 2017,

[2] A. Yusoff, S. Ismail, N. A. N. Rahman, and A. Muhamood, "Pengurusan kurikulum Pendidikan Khas Masalah Pembelajaran: Satu kajian awal dan keperluan inovasi," in Prosiding International Conference on Early Childhood and Special Education 2011, Pulau Pinang, Universiti Sains Malaysia, 2011.

[3] Unit Perancang Ekonomi Jabatan Perdana Menteri, Rancangan Malaysia Kesebelas 2016-2020 Pertumbuhan Berpaksikan Rakyat. Kuala Lumpur: Percetakan Nasional Malaysia Berhad, 2015.

[4] S. Nachiappan, K. Kamaruddin, A. A. Shukor, R. Jantan, R. Mustapha, and H. Hamzah, Pembelajaran dan perkembangan pelajar (Edisi kedua). Shah Alam: Oxford Fajar, 2012.

[5] Kementerian Pendidikan Malaysia, Spesifikasi Kurikulum Sains tingkatan 4. Putrajaya: Bahagian Pembangunan Kurikulum, 2010.

[6] Husin, M. R, Menilai gaya pembelajaran murid Bermasalah Pembelajaran dalam mata pelajaran Pendidikan Islam dan j-QAF. Tesis Doktor Falsafah: Universiti Pendidikan Sultan Idris, 2016.

[7] Kementerian Pendidikan Malaysia, Dokumen standard kurikulum dan pentaksiran. Kuala Lumpur: Bahagian Pendidikan Guru, 2015.

[8] R. A. Roesler, "Independence Pending: Teacher Behaviors Preceding Learner Problem Solving," Journal of Research in Music Education, vol. 64, no. 4, pp. 454-473, 2017.

[9] A. M. Din, "Pengurusan dan pentadbiran Pendidikan Islam di Malaysia," in Konvensyen Kebangsaan Pendidikan Islam 2011. Kuala Lumpur, Universiti Malaya, 2011.

[10] O. A. Kareem, "Pengurusan Pendidikan Islam: Apakah realiti memenuhi harapan," in Konvensyen Kebangsaan Pendidikan Islam 2011. Kuala Lumpur, Universiti Malaya, 2011.

[11] Z. Hussin, M. Soho, S. Siraj, A. A. Sapar, and N. N. Hasan, "Pengajaran dan pembelajaran Pendidikan Islam untuk murid berkeperluan khas sekolah rendah: Pelaksanaan dan masalah," in Prosiding International Conference and Exhibition on Research in Islamic and Arabic Language Education 2011, Langkawi, Hotel Awana Porto Malai, 2011.

[12] N. Wamba and K. J. Dunn, "Effective Individualized Educational Plans: Do Something Special with Learning Styles," Insights on Learning Disabilities, vol. 6, no. 1, pp. 1-11, 2009.

[13] A. Adnan and W. K. W. N Jamil, "Tuntutan dan tatacara solat murid pendidikan khas," in Prosiding Persidangan Antarabangsa Pendidikan Khas 2012, Melaka, Hotel Mahkota, 2012.

[14] H. M. Som, "Pengajaran dan pembelajaran Pendidikan Islam di Malaysia: Satu sorotan," in Konvensyen Kebangsaan Pendidikan Islam 2011, Kuala Lumpur, Universiti Malaya, 2012.

[15] C. Macintyre and P. Deponio, Identifying and supporting children with specific learning difficulties. London: RoutledgeFalmer, 2003.

[16] G. Hardaker and A. A. Sabki, "An insight into Islamic Pedagogy at the University of alQarawiyyin," Multicultural Education and Technology Journal, vol. 6, no. 2, pp. 106-110, 2012. 